\title{
Effect of Reduction Temperature and Time on The Reduction of Graphene Oxide with White Cabbage Extract
}

\author{
Nurşah KÜTÜK ${ }^{1 *}$, Sevil CETINKAYA GÜRER ${ }^{1}$ \\ ${ }^{1}$ Cumhuriyet University, Faculty of Engineering, Department of Chemical Engineering, Sivas, Turkey \\ (ORCID: 0000-0001-5799-3865) (ORCID: 0000-0001-5421-0474)
}

\begin{abstract}
Graphene is an important material that has attracted attention in recent years due to its large surface area, mechanical strength, thermal, electrical and magnetic properties. In this work, reduced graphene oxide (RGO) was obtained by reducing the graphene oxide (GO) with green synthesis. For this purpose, white cabbage aqueous extract was selected to reduce GO. The total phenolic acids, which are the reducing agent in the extract, were determined according to the Folin-Cioceltau method. It was determined that there is 0.064 grams of polyphenols in $1 \mathrm{~mL}$ of white cabbage extract. In order to determine the reduction experimental conditions, a reduction temperature of 25,50 and $100{ }^{\circ} \mathrm{C}$ and 1,2, 4 and 6 hours of reduction time were studied. Structural characterization of synthesized RGOs was performed with XRD, FTIR and SEM techniques. The results showed that GO was reduced at a reduction reaction temperature of $100{ }^{\circ} \mathrm{C}$ and a reduction reaction time of 6 hours. The peak seen at $22.08^{\circ}$ in the XRD data is evidence of reduction of GO.
\end{abstract}

\section{Beyaz Lahana Özütü ile Grafen Oksitin İndirgenmesi Üzerinde İndirgeme Sıcaklığı ve Süresinin Etkisi}

\begin{abstract}
$\ddot{O} \mathbf{z}$
Grafen, geniş yüzey alanı, mekanik dayanımı, 1sıl, elektriksel ve manyetik özellikleri nedeniyle son yıllarda dikkatleri üzerine çeken önemli bir malzemedir. Bu çalışmada grafen oksitin (GO) yeşil sentezle indirgenmesi ile indirgenmiş grafen oksit (RGO) elde edilmiştir. Bu amaçla, GO'yu indirgemek için beyaz lahana sulu özütü seçildi. Özütteki indirgeyici ajan olan toplam fenolik asitler Folin-Cioceltau yöntemine göre belirlendi. $1 \mathrm{~mL}$ beyaz lahana özütünde 0.064 gram polifenol olduğu tespit edildi. İndirgeme deney koşullarını belirlemek için 25,50 ve $100^{\circ} \mathrm{C}$ indirgeme sıcaklı̆̆ ve 1, 2, 4 ve 6 saatlik indirgeme sürelerinde çalışılmıştır. Sentezlenen RGO'ların yapısal karakterizasyonu XRD, FTIR ve SEM teknikleri ile yapıldı. Sonuçlar $100^{\circ} \mathrm{C}$ indirgeme reaksiyonu sıcaklığında ve 6 saat indirgeme reaksiyonu süresinde $\mathrm{GO}$ 'nun indirgendiğini göstermiştir. XRD verilerinde $22.08^{\circ}$ de görülen pik GO'nun indirgendiğinin kanıtıdır.
\end{abstract}

Anahtar kelimeler: İndirgenmiş grafen oksit, Yeşil sentez, Beyaz lahana, Polifenol

\section{Introduction}

Graphite, which is formed by the overlapping of graphene sheets with strong $\pi$ - $\pi$ interaction, is a common and inexpensive source [1]. Graphene is a material that attracts science and industry due to its many unique properties such as strength, large surface area, high thermal conductivity, hydrophobic structure and electronic, catalytic, magnetic properties [2,3]. Thanks to these properties, graphene is used in many different sectors such as medicine and energy [3]. The unique properties of graphene are due to the $\pi$ electrons in the $\mathrm{C}=\mathrm{C}$ bond [1]. It has a two-dimensional (2D) sheet of $\mathrm{sp}^{2}$ carbon atoms and very thin structure [4-7]. It is thought that graphene has an electron mobility of more than $15000 \mathrm{~cm}^{2} \mathrm{~V}^{-}$ 
${ }^{1} \mathrm{~S}^{-1}$ at room temperature and a thermal conductivity of around $5000 \mathrm{Wm}^{-1} \mathrm{~K}^{-1}$ and surface area is 2630 $\mathrm{m}^{2} / \mathrm{g}$ [8]. Some of the graphene synthesis methods are the top-down approach, micromechanical cleavage, solvothermal reduction, chemical reduction, laser irradation, liquid phase exfoliation, and the reduction of graphene oxide with chemical or vegetable agents $[9,10]$. Graphene oxide is a graphene allotrope similar to graphene with its hexagonal carbon structure. However, it has many oxygencontaining (hydroxy, carbonyl, carboxylic acid, alkoxy) functional groups. If functional groups containing oxygen are formed on the graphite surface, graphite oxide is formed. Graphene oxide is obtained by the expansion of graphite oxide layers [7, 11]. Both graphene and GO have large surface areas. However, GO can dissolve in water due to its oxygenated functional groups. In addition, it has an amphiphic structure [12]. There are many synthesis methods of GO such as Hummers, Brodie, Hofmann, Staundenmaier [13].

In recent years, RGO is known as one of the graphene production methods, which has been prominent in many fields such as nanotechnology [14]. Reduced graphene oxide (RGO) is similar in structure and properties to graphene [4]. It has been reported that the measure of reduction of GO or the extent of oxidation of graphene affects some properties of electrical conductivity, catalysis activity. The degree of reduction of graphene oxide is controlled by temperature and time [10]. Reduced graphene oxide (RGO) is a biocompatible material with superior mechanical strength and electrical conductivity [15]. Reducing chemicals such as hydrazine $\left(\mathrm{N}_{2} \mathrm{H}_{4}\right)$, hydrazine hydrate and sodium borohydride $\left(\mathrm{NaBH}_{4}\right)$ are frequently used to reduce GO. However, these chemicals are both toxic and harmful to the environment. Plant extracts (Lycium barbarum, Ginkgo biloba, Kombucha tea, carrot root, green tea, cinnamon, Chrysanthemum), cafffeic acid, organic acids, glucose, melatonin, vitamin $\mathrm{C}$ and some bacteria (Escherichia coli, E. fergusoni) have been used in recent years to reduce GO [3, 15-21]. White cabbage is an important vegetable that can be grown almost anywhere in the world. It belongs to the Cruciferae family. It has been reported that white cabbage is an important source of polyphenols [22, 23]. No studies of GO reduction with white cabbage extract have been reported to date.

In this study, it was aimed to obtain reduced GO by using white cabbage extract. Total phenolic content of white cabbage was determined by Folin-Cioceltau method. The effect of reaction temperature and reaction time on reduction was investigated by XRD, FTIR and SEM techniques.

\section{Material and Method}

\subsection{Materials}

The materials used in our experiments were gallic acid $\left(\mathrm{C}_{7} \mathrm{H}_{6} \mathrm{O}_{5}\right.$, Sigma-Aldrich) and sodium carbonate $\left(\mathrm{Na}_{2} \mathrm{CO}_{3}, 99 \%\right.$, Sigma-Aldrich), Folin-Cioceltau reagent (Carlo-Erba). White cabbage was obtained from local markets.

\subsection{Preparation of White Cabbage Extract}

About 100 grams of white cabbage cut into long strips. It was extracted by brewing by soaking in 500 $\mathrm{mL}$ distilled water $\left(\right.$ at $70^{\circ} \mathrm{C}$ ) for 30 minutes. The extract was obtained by filtration. The extract obtained was used fresh.

\subsection{Folin-Cioceltau Method}

The total amount of phenolic matter in white cabbage was determined according to the Folin-Cioceltau method. In the alkaline medium provided with $10 \mathrm{~mL}$ of supersaturated sodium carbonate, $1 \mathrm{~mL}$ of extract and $5 \mathrm{~mL}$ of Folin reagent and a blue solution of distilled water were prepared. It was kept in the dark for 1 hour. Then, absorbance was measured at $720 \mathrm{~nm}$ wavelength in UV-vis spectroscopy. With this method, the amount of reducing agent in white cabbage extract was determined.

\subsection{Synthesis of Reduced Graphene Oxide}


We used GO, which we reported in our previous article and synthesized by the Hummers method [19]. $50 \mathrm{mg}$ of $\mathrm{GO}$ was added (concentration $1 \mathrm{mg} / \mathrm{mL}$ ) into $50 \mathrm{~mL}$ of white cabbage extract and kept in an ultrasonic water bath at room temperature for 1 hour until it became homogeneous. Then, $50 \mathrm{~mL}$ more white cabbage extract was added onto this sonicated mixture. In this way, the concentration of the suspension was brought to the level of $0.5 \mathrm{mg} / \mathrm{mL}$. The reaction vessel connected to the spiral refluxer was stirred at $400 \mathrm{rpm}$ at different reaction temperatures $\left(25,50,100{ }^{\circ} \mathrm{C}\right)$ and times $(1,2,4$ an $6 \mathrm{~h})$, and the black solution obtained was precipitated by centrifugation and dried at $60^{\circ} \mathrm{C}$ for 24 hours. The visual version of the method we use to reduce GO is given in Figure 1.

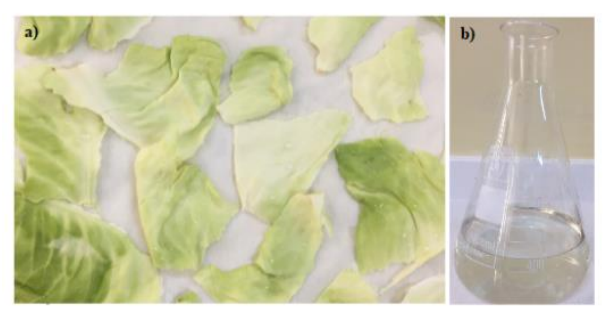

a) White cabbage, b) extract

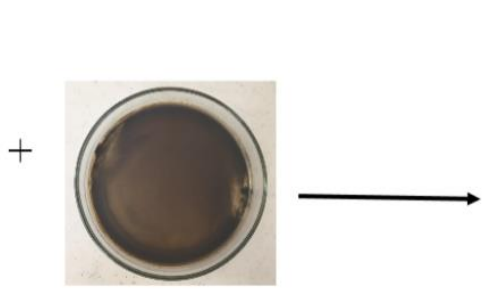

GO synthesized by the Hummers method
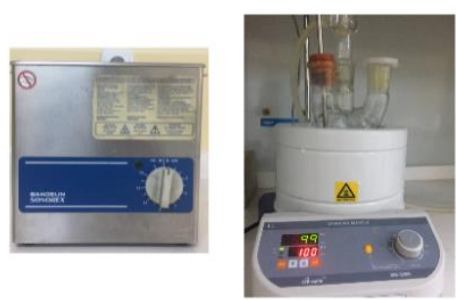

Sonication and mixing

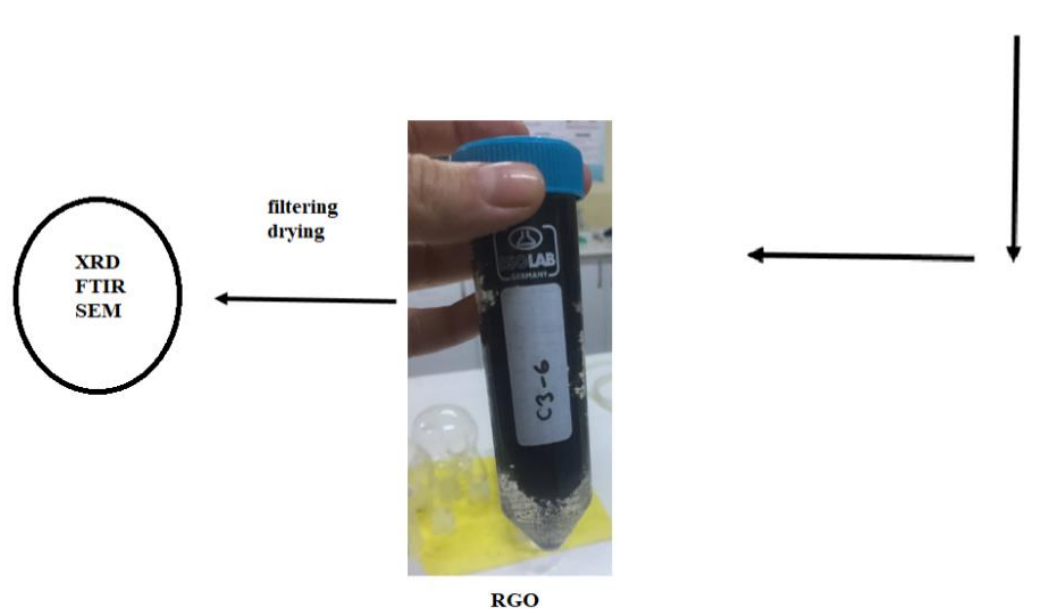

Figure 1. Schematic view of the reduction of GO with white cabbage extract

\section{Results and Discussion}

Gallic acid (GA) solution with ethanol was used to determine the total phenolic content. Because gallic acid is the equivalent of polyphenol. For this purpose, GA solution at different concentrations $(1,10$, $20,100,250,375 \mathrm{mg} / \mathrm{L}$ ) was prepared and the calibration graph was prepared in Figure 2 by measuring the absorbance values at $720 \mathrm{~nm}$. The total amount of phenolic matter in the white cabbage extract was determined from the equation $(\mathrm{y}=0.0049 \mathrm{x}+0.0945)$ obtained from the graph. It has been calculated that there is 0.064 grams of total phenolic substance in $1 \mathrm{~mL}$ of white cabbage extract. 


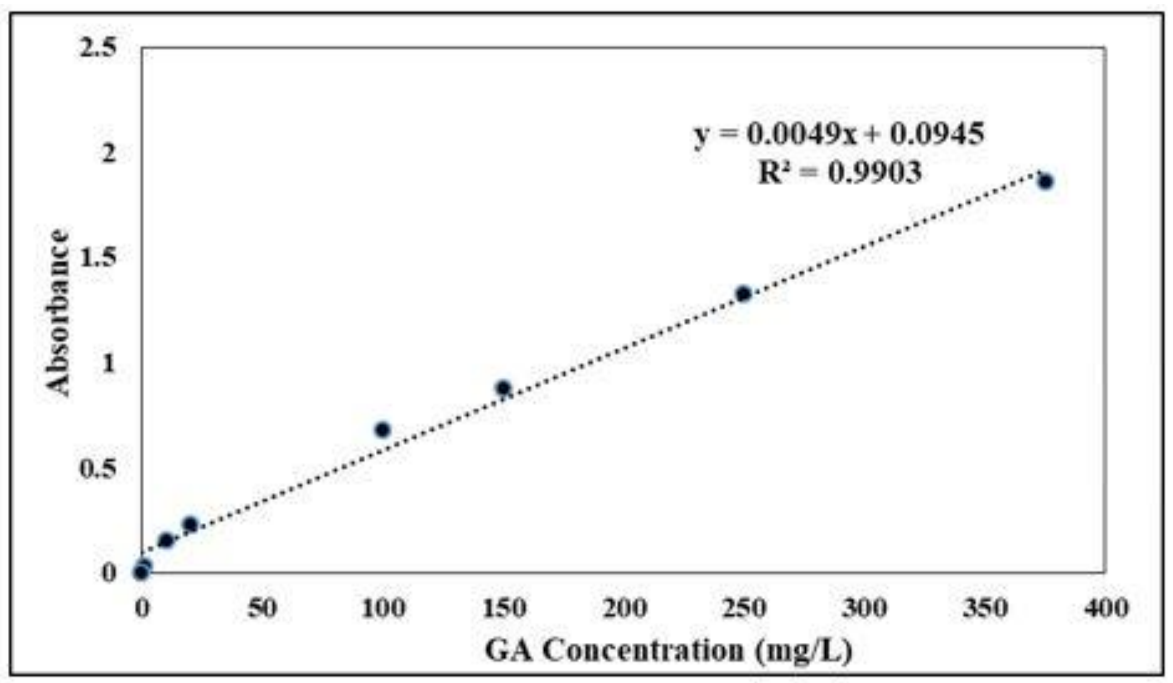

Figure 2. Gallic acid calibration graph

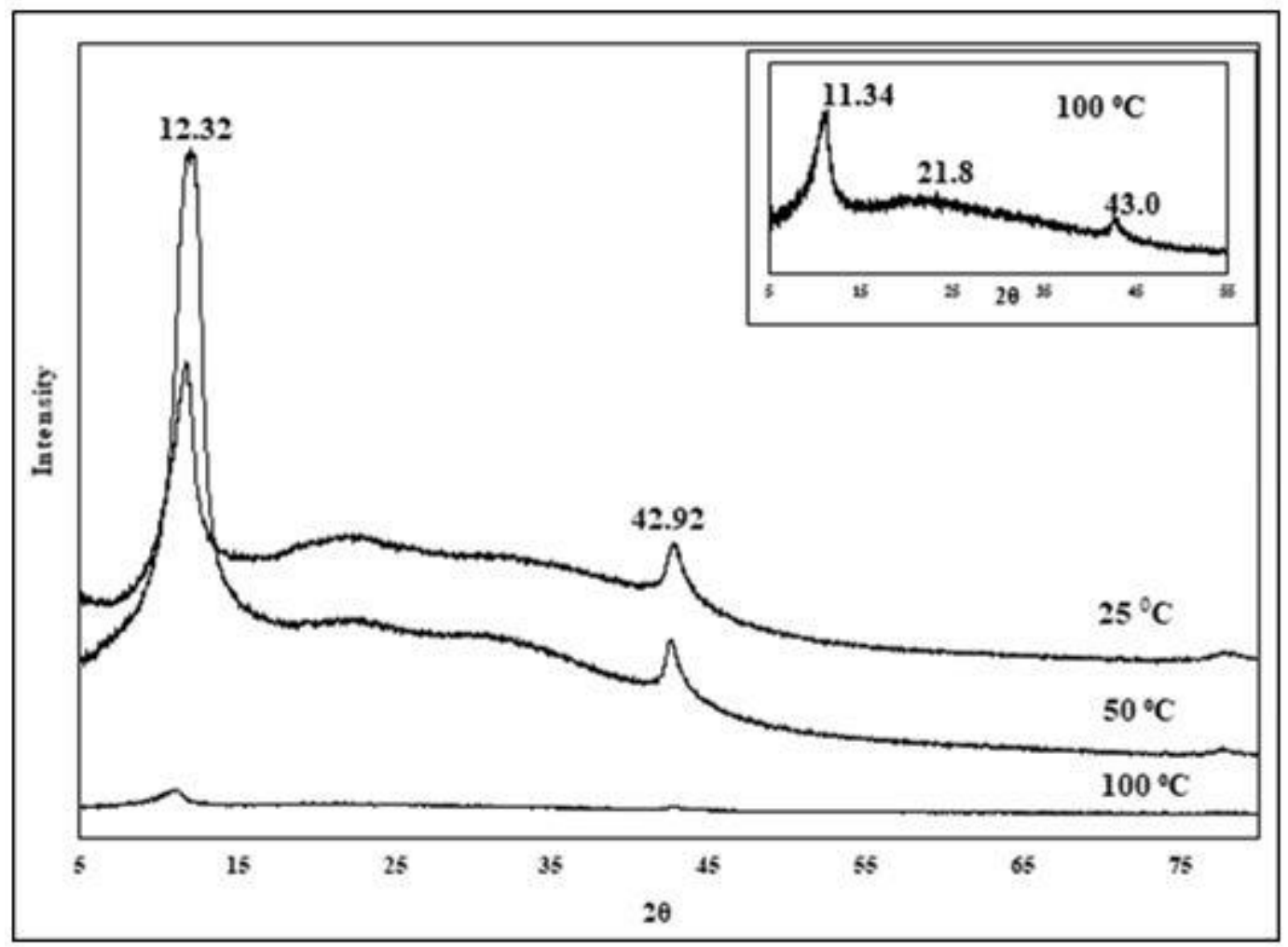

Figure 3. XRD spectra of RGO samples prepared at different reaction temperatures using white cabbage extract (Reaction time 1 hour).

Using white cabbage extract, RGO samples were prepared at reaction temperatures of 25,50 and $100^{\circ} \mathrm{C}$, with a constant reaction time of 1 hour. The properties of the prepared RGO samples were examined using XRD and FTIR techniques. According to XRD data in the literature, graphite gives a peak in the range of $25-26^{\circ}$, while GO gives a peak between 11-13 ${ }^{\circ}$ [19]. XRD spectra of RGO samples prepared with white cabbage extract at different reaction temperatures are given in Figure 3. In the RGO samples synthesized at 25 and $50^{\circ} \mathrm{C}$, characteristic peaks of $\mathrm{GO}$ at $2 \theta=12.32^{\circ}$ and $42.92^{\circ}$ were clearly observed. It is seen that the peak intensity of GO at $2 \theta=12.32^{\circ}$ decreases significantly when the temperature rises to $100^{\circ} \mathrm{C}$. In addition, in this sample, it was observed that the peak of GO at $2 \theta=12.32^{\circ}$ shifted to the left to $2 \theta=11.34^{\circ}$. The low intensity peak at $2 \theta=42.92^{\circ}$ indicates the graphene crystal plane structure [18]. The inter-layer distance for RGO was calculated by Bragg's law (Eq. 1) [24]. RGO peak 
seen at $2 \theta=21.8^{\circ}$ for the reaction temperature of $100^{\circ} \mathrm{C}$, the interlayer distance was calculated as 0.41 nm.

$\lambda=2 d \sin \theta$

In the formula, $\mathrm{d}$ is the distance between the layers and theta is the angle of diffraction. $\lambda$ is $0.154056 \mathrm{~nm}$ wavelength value. The average crystal size (Dp) of the RGO samples was calculated with the Debye-Scherer equation (Eq. 2) using the Full Width at Half Maximum (FWHM) values obtained from the XRD graph.

$D p=K \lambda / \beta \cos \theta$

Where Dp is the average crystallite size, $\mathrm{K}$ is the Scherrer constant (0.94). $\lambda$ is the wavelength, $\beta$ is the full width at half the maximum intensity (FWHM) and $\theta$ is the diffraction angle in degrees [25].

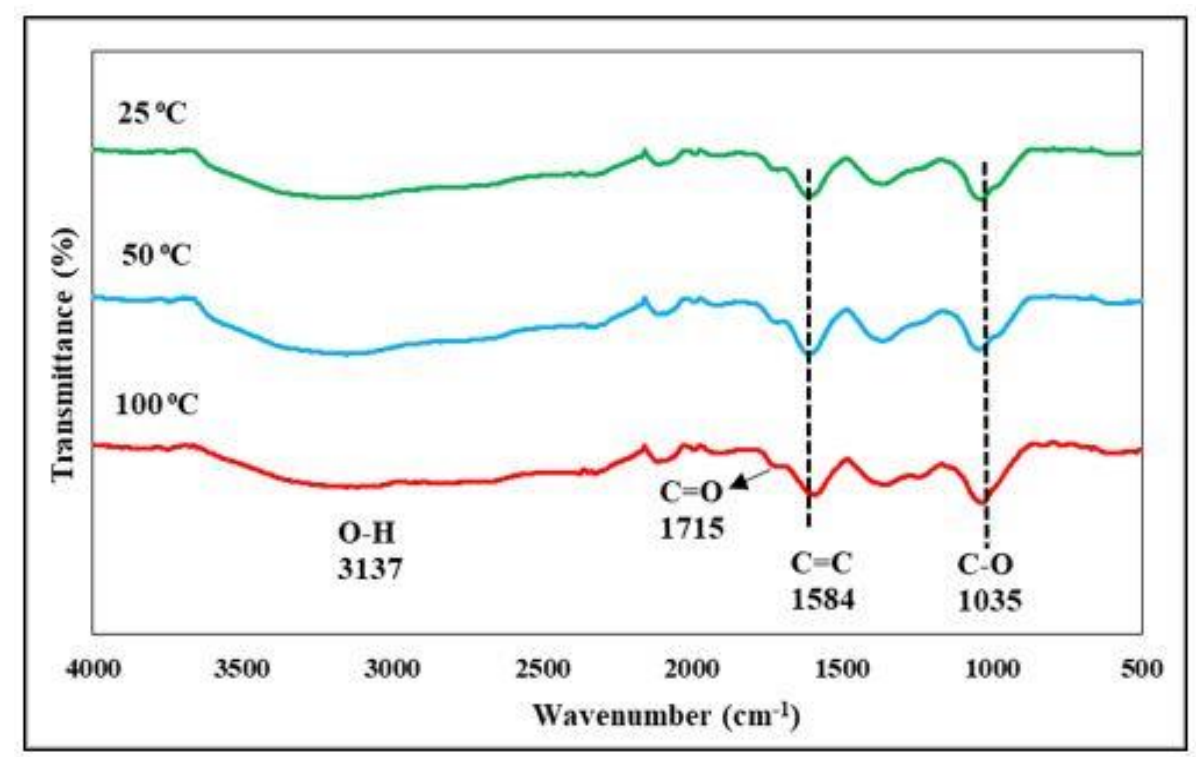

Figure 4. FTIR spectrum of RGO samples prepared at different reaction temperatures using white cabbage extract (Reaction time 1 hour).

The FTIR spectrum of the RGO samples prepared by using white cabbage extract at 25, 50 and $100{ }^{\circ} \mathrm{C}$ reaction temperature with by 1 hour reaction time are shown in Figure 4. There are many functional groups on the GO surface. IR absorption peak values of functional groups on the GO surface in the literature are given in Table 1. In Figure 4, the peaks seen at 1035, 1584, 1715 and $3137 \mathrm{~cm}^{-1}$ on RGO surfaces show $\mathrm{C}-\mathrm{O}$ (alkoxy) stretch, $\mathrm{C}=\mathrm{C}$ aromatic stretch vibration, $\mathrm{C}=\mathrm{O}$ stretch and $\mathrm{O}-\mathrm{H}$ (hydroxyl) vibration respectively. The intensity of the peak corresponding to the $\mathrm{C}=\mathrm{O}$ vibration band at $1715 \mathrm{~cm}^{-1}$ decreased with the increase in temperature $[14,26]$. The permeability intensity of the hydroxyl group $\left(3137 \mathrm{~cm}^{-1}\right)$ decreased as the temperature increased from $25^{\circ} \mathrm{C}$ to $100^{\circ} \mathrm{C}$. The reason for this is that the absorbed water molecules evaporate by intercalation as the temperature increases. In addition, GO is reduced by losing the presence of oxygen-containing functional groups and its hydrophilic properties [14].

Table 1. Functional groups on GO surface and IR absorption peak values in the literature [19, 27]

\begin{tabular}{ll}
\hline Peak position $\left(\mathrm{cm}^{-1}\right)$ & Functional group \\
\hline $3000-3500$ & O-H \\
$1700-1750$ & C=O \\
$1550-1650$ & C=C \\
$1000-1100$ & C-O \\
\hline
\end{tabular}


The reduction temperature was chosen as $100^{\circ} \mathrm{C}$ because of the peak attributed to the graphene structure in the XRD data at $2 \theta=21.8^{\circ}$ and the functional peak intensities of oxygen-containing groups decreased slightly. XRD data of RGO samples prepared for 1,2, 4 and 6 hours at a reduction temperature of $100{ }^{\circ} \mathrm{C}$ are shown in Figure 5. The characteristic peak of GO has emerged in the range of $2 \theta=11.4-$ $11.62^{\circ}$, shifted to the left for RGO samples prepared in 1, 2 and 4 hours reduction times. The characteristic wide and small peak of RGO prepared in 4 hours mixing period was seen at $2 \theta=23.3^{\circ}$, and this peak is not seen in RGO samples prepared at 1 and 2 hours mixing times. When the reaction time reached 6 hours, a wide and distinct characteristic peak of RGO was observed at $2 \theta=22.08^{\circ}$. For this peak, the distance between the layers can be calculated as $0.40 \mathrm{~nm}$. According to literature, it can be concluded that this value is smaller than the distance between the layers $(0.7-0.98 \mathrm{~nm})$ of GO [17]. For this example, GO's peak was observed at $2 \theta=13.2^{\circ}$. From the results, it can be said that the peak of RGO appears and peak of GO is reduced in direct proportion to the increase in reaction time [28]. According to Eq. 2, the average crystal size in the sample prepared with $100{ }^{\circ} \mathrm{C}$ reaction temperature and 6 hours reduction time was determined as $0.51 \mathrm{~nm}$.

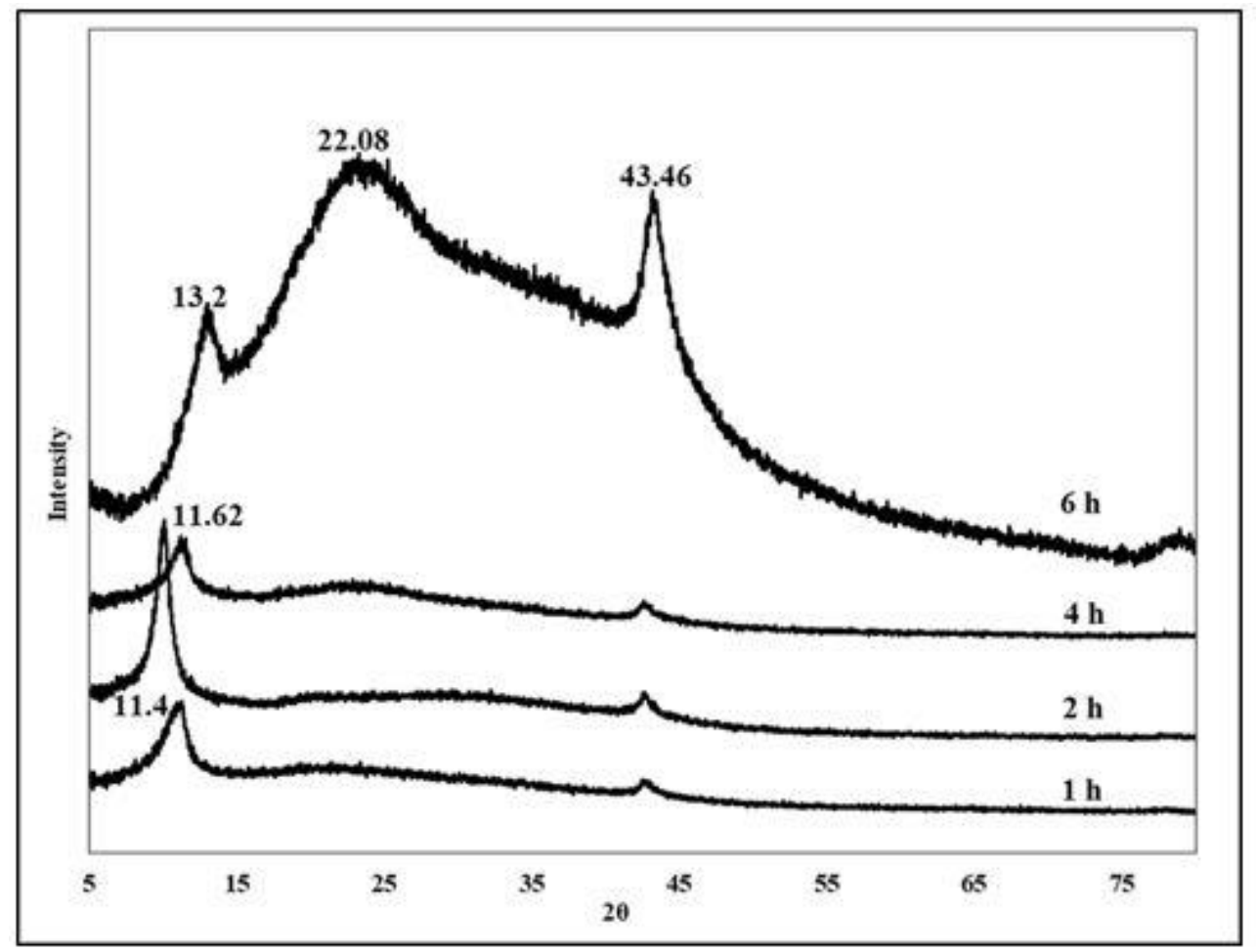

Figure 5. XRD spectrum of RGO samples prepared at different reaction times using white cabbage extract (Reaction temperature $100^{\circ} \mathrm{C}$ ).

From the FTIR spectra where the effect of the reaction time for RGO obtained using white cabbage extract was investigated, reduction appears to be more effective after 2 hours (Figure 6). For RGOs prepared at the 4th and 6th hour, the peak intensity $(\mathrm{O}-\mathrm{H})$ at $3137 \mathrm{~cm}^{-1}$ and the intensity of the alkoxy (C-O) peak at $1045 \mathrm{~cm}^{-1}$ decreased significantly. Because the reducing temperature was chosen as $100{ }^{\circ} \mathrm{C}$, free water molecules intercalated in $\mathrm{GO}$ evaporated, weakening the peak intensity of the O$\mathrm{H}$ functional groups $[26,28]$. When the results obtained from FTIR and XRD are evaluated together, it is concluded that suitable conditions for the reduction of GO can be achieved using white cabbage extract at a reduction temperature of $100^{\circ} \mathrm{C}$ and a reduction time of 6 hours. 


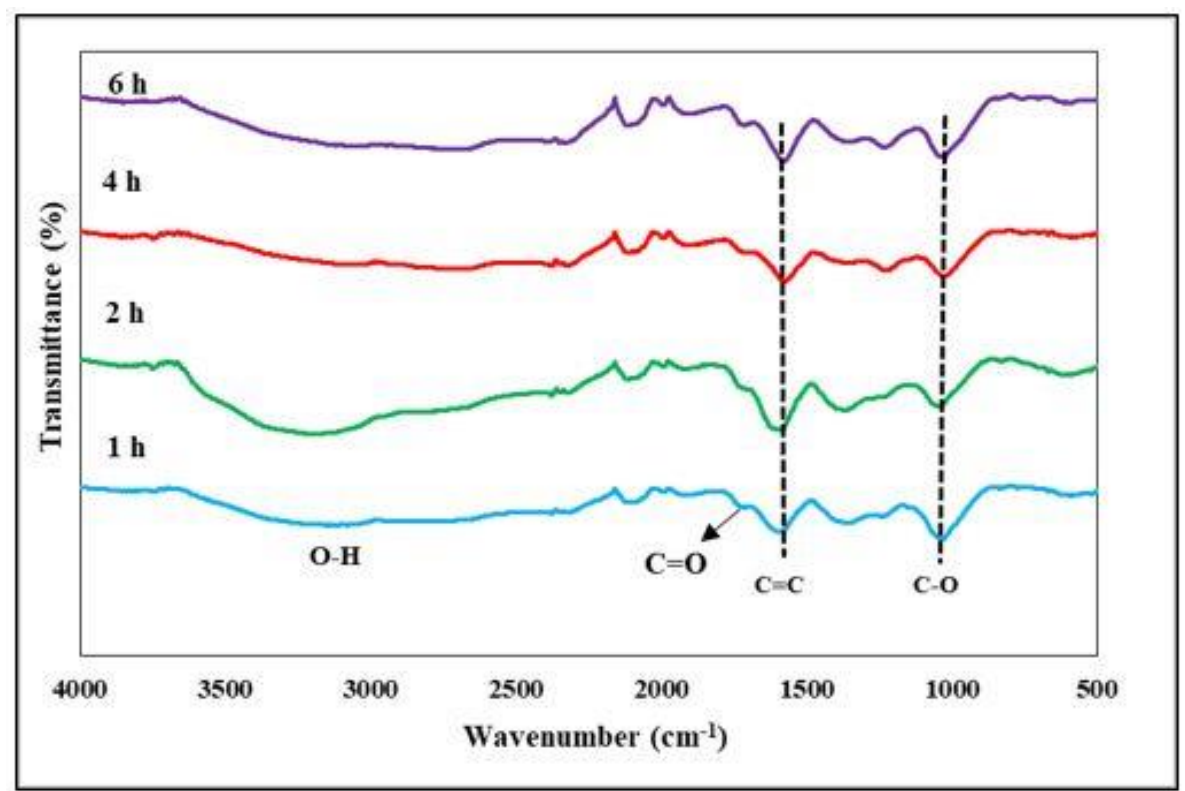

Figure 6. FTIR spectrum of RGO samples prepared at various reaction times using white cabbage extract (Reaction temperature $100^{\circ} \mathrm{C}$ ).
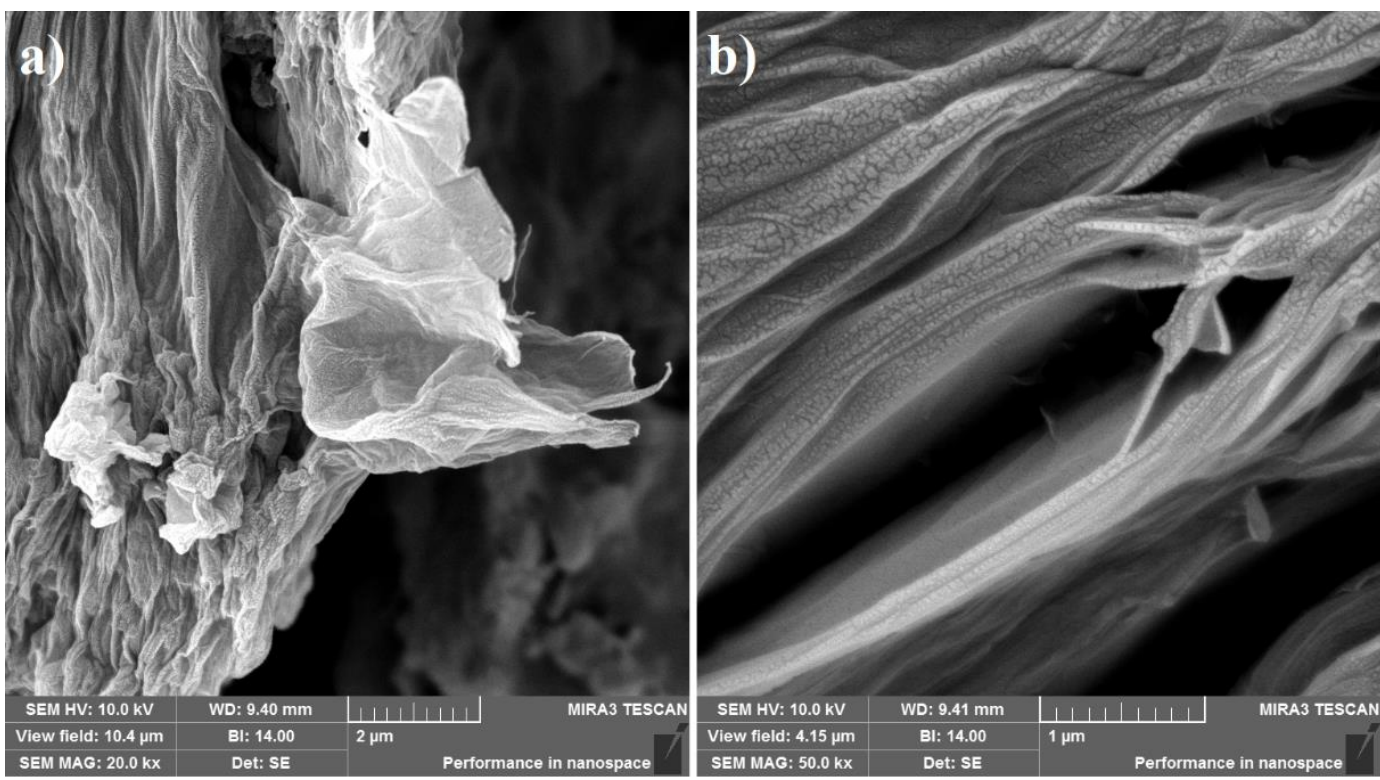

Figure 7. SEM images of RGO from different angles a) $20 \mathrm{k}$ magnification b) 50k magnification (Reaction temperature $100^{\circ} \mathrm{C}$, reaction time 6 hours)

SEM images of the prepared RGO sample at $100^{\circ} \mathrm{C}$ for 6 hours is shown in Figure $7 \mathrm{a}, \mathrm{b}$. In Figure $7 \mathrm{a}$, it is seen that there is agglomeration in the structure of RGO. Figure 7b illustrated that multilayer RGO was synthesized. In addition, it seen that prepared RGO sample formed undulating ripple-like layers had the basic properties of graphene (Fig.7b). Also, it is clear that after the GO is reduced, the wrinkled sheets increased and randomly collected [30]. It can be said that oxygencontaining functional groups decrease with increasing reaction temperature and so by removing these groups from the RGO surface, shrinkage occurs [14, 29].

\section{Conclusion}

Green synthesis has been applied to an environmentally friendly method by using extract instead of harmful chemicals. In this study, the reduction was achieved by removing the functional groups on the GO surface using white cabbage extract. According to the XRD and FTIR data, it can be said that suitable experimental conditions can be provided for the reduction of GO when the reduction 
temperature is $100{ }^{\circ} \mathrm{C}$ and the reduction time is 6 hours. In the SEM results, it was determined that the morphological structure of RGO is multi-layered. These results revealed that white cabbage extract can be used in the reduction of GO. When the literature is examined, it is seen that the reduction temperature of GO has been tested at different temperatures. However, the commonly chosen temperature in the studies is the range of $95-100{ }^{\circ} \mathrm{C}$. Similarly, the reduction temperature was determined as $100{ }^{\circ} \mathrm{C}$ in our study. This study indicates that white cabbage extract can be used as an alternative reducer instead of toxic chemicals, thanks to the polyphenol it contains.

\section{Acknowledgements}

This study was supported by Sivas Cumhuriyet University Scientific Research Projects (CÜBAP), project number as M702.

\section{Authors' Contributions}

In this study, Author 1 contributed to the literature review, experiments, evaluation of data and article writing, while Author 2 contributed to the formation of ideas, evaluation of the data, and article writing and editing.

\section{Statement of Conflicts of Interest}

There is no conflict of interest between the authors.

\section{Statement of Research and Publication Ethics}

The authors declare that this study complies with Research and Publication Ethics

\section{References}

[1] Gebreegziabher G.G., Asemahegne A.S., Ayele D.W., Dhakshnamoorthy M. 2019. One-step synthesis and characterization of reduced graphene oxide using chemical exfoliation method. Materials Today Chemistry, 12: 233-239.

[2] Hosseinzadeh A., Bidmeshkipour S., Abdi Y., Arzi E., Mohajerzadeh S. 2018. Graphene based strain sensors: A comparative study on graphene and its derivatives. Applied Surface Science, 448: 71-77.

[3] Gurunathan S., Han J.W., Park J.H., Eppakayala V., Kim J.H. 2014. Ginkgo biloba: A natural reducing agent for the synthesis of cytocompatible graphene. International Journal of Nanomedicine, 9 (1): 363-377.

[4] Wang J., Salihi E.C., Šiller L. 2017. Green reduction of graphene oxide using alanine. Materials Science and Engineering C, 72: 1-6.

[5] Narayanan D.P., Gopalakrishnan A., Yaakob Z., Sugunan S., Narayanan B.N. 2020. A facile synthesis of clay - graphene oxide nanocomposite catalysts for solvent free multicomponent Biginelli reaction. Arabian Journal of Chemistry, 13 (1): 318-334.

[6] Park Y.H., Park S.Y., In I. 2015. Direct noncovalent conjugation of folic acid on reduced graphene oxide as anticancer drug carrier. Journal of Industrial and Engineering Chemistry, 30: 190-196.

[7] Smith A.T., LaChance A.M., Zeng S., Liu B., Sun L. 2019. Synthesis, properties, and applications of graphene oxide/reduced graphene oxide and their nanocomposites. Nano Materials Science, 1: 31-47.

[8] Charmi J., Nosrati H., Mostafavi Amjad J., Mohammadkhani R., Danafar H. 2019. Polyethylene glycol (PEG) decorated graphene oxide nanosheets for controlled release curcumin delivery. Heliyon, 5 (4): e01466.

[9] Ismail Z. 2019. Green reduction of graphene oxide by plant extracts: A short review. Ceramics International, 45 (18): 23857-23868. 
[10] Xu C., Yuan R.S., Wang X. 2014. Selective reduction of graphene oxide. New Carbon Materials, 29 (1): 61-66.

[11] Romero A., Lavin-Lopez M.P., Sanchez-Silva L., Valverde J.L., Paton-Carrero A. 2018. Comparative study of different scalable routes to synthesize graphene oxide and reduced graphene oxide. Materials Chemistry and Physics, 203: 284-292.

[12] McCoy T.M., Turpin G., Teo B.M., Tabor R.F. 2019. Graphene oxide: a surfactant or particle? Current Opinion in Colloid and Interface Science, 39: 98-109.

[13] Bhunia P., Kumar M., De S. 2019. Rapid and efficient removal of ionic impurities from graphene oxide through hollow fiber diafiltration. Separation and Purification Technology, 209: $103-111$.

[14] Jaafar E., Kashif M., Sahari S.K., Ngaini Z. 2019. Effects of reduction temperatures on morphological, optical, and electrical properties of reduced graphene oxide (rGO) thin films. Materials Today: Proceedings, 16: 1702-1707.

[15] Barra A., Ferreira N.M., Martins M.A., Lazar O., Pantazi A., Jderu A.A., Neumayer S.M., Rodriguez B.J., Enăchescu M., Ferreira P., Nunes C. 2019. Eco-friendly preparation of electrically conductive chitosan - reduced graphene oxide flexible bionanocomposites for food packaging and biological applications. Composites Science and Technology, 173: 53-60.

[16] Esfandiar A., Akhavan O., Irajizad A. 2011. Melatonin as a powerful bio-antioxidant for reduction of graphene oxide. Journal of Materials Chemistry, 21 (29): 10907-10914.

[17] Hou D., Liu Q., Cheng H., Li K., Wang D., Zhang H. 2016. Chrysanthemum extract assisted green reduction of graphene oxide. Materials Chemistry and Physics, 183: 76-82.

[18] Hou D., Liu Q., Cheng H., Zhang H., Wang S. 2017. Green reduction of graphene oxide via Lycium barbarum extract. Journal of Solid State Chemistry, 246: 351-356.

[19] Çetinkaya Gürer S., Kütük N. 2019. Green reduction of graphene oxide by using kombucha tea. Eskişehir Technical University Journal of Science and Technology A - Applied Sciences and Engineering, 20: 24-29.

[20] Abdolahad M., Janmaleki M., Mohajerzadeh S., Akhavan O., Abbasi S. 2013. Polyphenols attached graphene nanosheets for high efficiency NIR mediated photodestruction of cancer cells. Materials Science \& Engineering C, 33 (3): 1498-1505.

[21] Suresh D., Kumar M.A.P., Nagabhushana H., Sharma S.C. 2015. Cinnamon supported facile green reduction of graphene oxide, its dye elimination and antioxidant activities. Materials Letters, 151: 93-95.

[22] Samec D., Pavlovic I., Salopek-Sondi B. 2017. White cabbage (Brassica oleracea var. capitata f. alba): botanical, phytochemical and pharmacological overview. Phytochemistry Reviews, 16: $117-135$.

[23] Singh J., Upadhyay A.K., Bahadur A., Singh B., Singh K.P., Rai M. 2006. Antioxidant phytochemicals in cabbage (Brassica oleracea L. var. capitata). Scientia Horticulturae, 108: 233-237.

[24] Sadhukhan S., Kumar T., Roy I., Rana D., Bhattacharyya A., Saha R., Chattopadhyay S., Khatua S., Acharya K., Chattopadhyay D. 2019. Green synthesis of cadmium oxide decorated reduced graphene oxide nanocomposites and its electrical and antibacterial properties. Materials Science and Engineering C, 99: 696-709.

[25] Tiyek İ., Dönmez U., Yıldırım B., Alma M.H., Ersoy M.S., Karataş Ş., Yazıcı M. 2016. Synthesis of reduced graphene oxide by chemical method and its characterization. SAÜ Fen Bilimleri Dergisi, 20 (2): 349-57.

[26] Andrijanto E., Shoelarta S., Subiyanto G., Rifki S. 2016. Facile synthesis of graphene from graphite using ascorbic acid as reducing agent. AIP Conference Proceedings, 17-25 April, 020003.

[27] Kassaee M.Z., Motamedi E., Majdi M. 2011. Magnetic $\mathrm{Fe}_{3} \mathrm{O}_{4}$-graphene oxide / polystyrene: Fabrication and characterization of a promising nanocomposite. Chemical Engineering Journal, 172 (1): 540-549.

[28] Sreeja V.G., Vinitha G., Reshmi R., Anila E.I., Jayaraj M.K. 2017. Effect of reduction time on third order optical nonlinearity of reduced graphene oxide. Optical Materials, 66: 460-468.

[29] Chong S.W., Lai C.W., Abdul Hamid S.B. 2015. Green preparation of reduced graphene oxide using a natural reducing agent. Ceramics International, 41 (8): 9505-9513. 
[30] Wang X., Hu Y., Min J., Li S., Deng X., Yuan S., Zuo X. 2018. Adsorption characteristics of phenolic compounds on graphene oxide and reduced graphene oxide: A batch experiment combined theory calculation. Applied Sciences, 8 (10): 1-13. 